International Journal on Emerging Mathematics Education (IJEME)

Vol. 1, No. 2, September 2017, pp. 177-184

P-ISSN: 2549-4996, E-ISSN: 2548-5806, DOI: http://dx.doi.org/10.12928/ijeme.v1i2.5783

\title{
Creative Thinking Process based on Wallas Model in Solving Mathematics Problem
}

\author{
${ }^{1}$ Hevy Risqi Maharani, ${ }^{2}$ Sukestiyarno, ${ }^{2}$ Budi Waluya \\ ${ }^{1}$ Mathematics Education Department, Sultan Agung Islamic University \\ ${ }^{2}$ Mathematics Education Department, Semarang State University \\ e-mail: hevyrisqi@unissula.ac.id
}

\begin{abstract}
Abstrak
Suatu hal yang sulit bagi guru SMP adalah memposisikan dan mengembangkan anak didiknya yang masih berada pada masa transisi dalam berpikir kreatif. Penelitian ini bertujuan untuk mengevaluasi proses berpikir kreatif siswa berdasarkan model Wallas. Penelitian ini ada penelitian deskriptif kualitatif menggunakan data triangulasi. Subjek dikategorikan pada kemampuan tinggi, sedang, dan rendah setelah diberikan tes kemampuan berpikir kreatif. Objek pada penelitian ini adalah eksistensi bagaimana siswa SMP dalam menyelesaikan masalah matematika. Data dianalisis melalui klasifikasi, representasi, dan kesimpulan. Hasil penelitian menunjukkan 1) terdapat 23,33\% siswa tidak tuntas dan hanya mencapai tahap persiapan, disebut kelompok kategori rendah; 2) terdapat $60 \%$ siswa mencapai tahap iluminasi meskipun untuk sampai pada tahap ini siswa memerlukan waktu lama, disebut kelompok kategori sedang; dan 3) 16,67\% siswa telah tuntas sampai tahap verifikasi, disebut kelompok kategori tinggi. Bagi siswa dengan kategori kemampuan rendah dan sedang masih membutuhkan pendampingan saat mengalami hambatan pada proses berpikir kreatifnya, sedangkan siswa kategori kemampuan tinggi membutuhkan materi pengayaan.
\end{abstract}

Kata kunci: proses berpikir kreatif, masalah matematika, Model Wallas

\begin{abstract}
Developing student's creative thiking is difficult for teacher, especially when they are still in transtition. This study aims to evaluate students' creative thinking process based on the model of Wallas. This is a descriptive and qualitative research where data triangulation is employed. Subjects are categorized into upper, middle, and low category after doing creative thinking ability test. The object of the study is the existence of how junior high school's students solving mathematics problems. Data were analyzed through classification, data representation, and conclusions. The results showed 1) $23,33 \%$ of students only reached preparation stage, called low category, 2) $60 \%$ of students reached illumination stage though students take a long time, called middle category, and 3) $16,67 \%$ of students have completed up to verification stage, called upper category. For students in low and middle category, they still need assistance when experiencing obstacles in the creative thinking process, while the upper category students need enrichment materials.
\end{abstract}

Keywords: creative thinking process, mathematics problem, Wallas model

How to Cite: Maharani, H.R., Sukestiyarno, \& Waluya, B. (2017). Creative thinking process based on wallas model in solving mathematics problem. International Journal on Emerging Mathematics Education, 1(2), 177-184. http://dx.doi.org/10.12928/ijeme.v1i2.5783

\section{INTRODUCTION}

The development of creative thinking is now expected to be the focus of mathematics education in which students are given the freedom to try to give original or new possible solutions from themselves (Kwon, Park, \& Park, 2006). It means, learning mathematics should avoid the use of traditional learning methods that leads to convergent thinking in which students only remember mathematical theorems and 
rules to solve problems. In reality, what often happens in mathematics learning is students are given closed problems to be solved. Students are not taught to use divergent thinking and reasoning which is important for them to understand the context so that they give a positive response and actively participate in the learning process.

Students who have a creative thinking not only uses mathematical knowledge they have acquired during the learning in solving the problem, but can use new strategies and unusual in solving their problems (Wessels, 2014). Pehkonen (1997) give four reasons why it is important to teach problem solving in relation to creative thinking. First, problem solving can develop cognitive skills. Second, problem solving encourages creativity. Third, problem solving is a part of the process to apply mathematics. And the last, problem solving encourages students to learn mathematics. In Bloom taxonomy, there are two dimensional frameworks: knowledge and cognitive process (Bloom, 1956; Krathwohl, 2002; Huitt, 2011; Bonaci, Mustata \& Ienciu, 2013; Munzenmaler \& Rubin, 2013; IACBE, 2014). Structure of the knowledge dimension includes factual, conceptual, procedural, and metacognitive knowledge. Structure of the cognitive process dimension includes remember, understand, apply, analyze, evaluate, and create. Create is the highest dimension on cognitive process. Students must have creative thinking ability to get it.

Highlighting the sub areas of mathematics, especially geometry, the material consists of concepts that students need more attention to understand them. For instance, junior high school students need transition of thinking process from the concrete to the abstract. The study of Maharani \& Sukestiyarno (2015) showed that the average student's mathematics creative thinking ability on geometry were categorized in almost not creative. There were no students in creative or very creative category. Students in solving the problems still use one particular way that has been taught by their teacher. they were not familiar using variety of ways in solving a problem. The solution given by students were not categorized in a new or unusual idea. Very rare students gave the answer in any variety of ways.

Creative thinking ability on the concept of geometry in junior high school cannot be separated from problem solving ability. In defining the relationship between creative thinking and problem solving, it is important to determine what makes creative of creative problem solving. Therefore, it is important to do an investigation of the creative thinking process (Aldous, 2007). One model of the creative thinking process is presented by Wallas (2014). The model consists of four distinct stages: preparation, incubation, illumination, and verification. In the preparation stage we collect a wide range of knowledge, share this knowledge into rules of logic in the realm of the investigation and adopted to define a given problem. During the incubation stage, various ideas freely grouped and rearranged without students directly working on the problem. This stage requires a few seconds, minutes, or hours depending on the difficulty of the problems encountered. Usually when the solution is found, the illumination stage has arrived which is often called as the 'aha' experience. At the end, the obtained solution need to be checked, developed, and refined in the verification stage and elaborated to ensure the solutions is understandable. If the verification stage showed a solution to be not feasible then there may be a return to the beginning of creative process. Although preparation and verification stages are included in the conscious activity, incubation and illumination stages are in unconscious activity.

In school, students have differences from the other students in many various domains. They have different levels of motivation, background, attitude towards teaching

IJEME, Vol. 1, No. 2, September 2017, 177-184 
and learning, as well as different responses to the classroom environment and certain instructional practices (Potur \& Barkul, 2009; Runisah, Herman, \& Dahlan, 2017). As a result, students have differences in creative thinking process. The purpose of this study is to evaluate student's creative thinking process in solving mathematics problems. If the teachers know the process of creative thinking, the teacher can give the specific assistance to students and can select model or method that appropriate for students.

The framework of this study is junior high school students who are in a transition of creative thinking process. In Sari \& Sukestiyarno (2014), Widiastuti \& Sukestiyarno (2014), and Wulandari \& Sukestiyarno (2015), they suggest that in order to achieve the goal of students such as the mastery of cognitive ability in creative thinking, they must be trained to perform conditional affective aspects of creative that is focused under a specified time period. The model of Wallas is used to measure and determine student's position in creative thinking stages. Therefore the following study is conducted under the research aims of describing the profil of student's creative thingking in solving mathematics problems based on Wallas model.

\section{RESEARCH METHOD}

This study uses a descriptive qualitative approach. Variable of this study is junior high school student's creative thinking process in solving mathematics problem. Data were collected through tests of mathematics problem solving that are evaluated based the model of Wallas (2014). Subjects were students of class VII Sultan Agung Junior High School. They were selected through purposive sampling technique that is based on several criteria. The first criterion is based on the level of student's creative thinking ability. The number of subjects at each level contains a minimum of two students. The second criterion is to choose students who have a good communication skill. The creative thinking process of students in solving mathematics problems is observed based on Wallas model. The procedure of this study as follows: 1) provide a test of mathematics problem solving to students; 2) analyze the results of students in solving mathematics problem to identify the abilities of students in creative thinking; 3) conduct interviews for students to know their creative thinking process in solving mathematics problem; 4) analyze the results of interviews.

\section{RESULTS AND DISCUSSION}

Students were given a mathematics problem in geometry which is open question where some alternative answers are possible. The results of the analysis of student's answers in solving mathematics problems showed that 5 students have mathematics creative thinking ability in upper category $(16,67 \%), 18$ students have mathematics creative thinking ability in middle category (60\%), and 7 students have mathematics creative thinking ability in lower category $(23,33 \%)$. Furthermore, in each category of creative thinking ability, two representatives were interviewed.

For students in upper category, they went through the stages of creative thinking process of Wallas very well. When students are trying to find alternative answers, they always taking into account the available time to convince whether the answer is correct. Controlling the answer is something that is very important to them. Figure 1 is an example of the creativity of the students to arrange several plane figures that have same areas with an area of a given plane figure. The first alternative, student made arrangement of four rectangles with a length is 15 and width is 4 . In the second alternative, student can make arrangement some plane figures that consist of rectangle and triangle shown in Figure 1. 


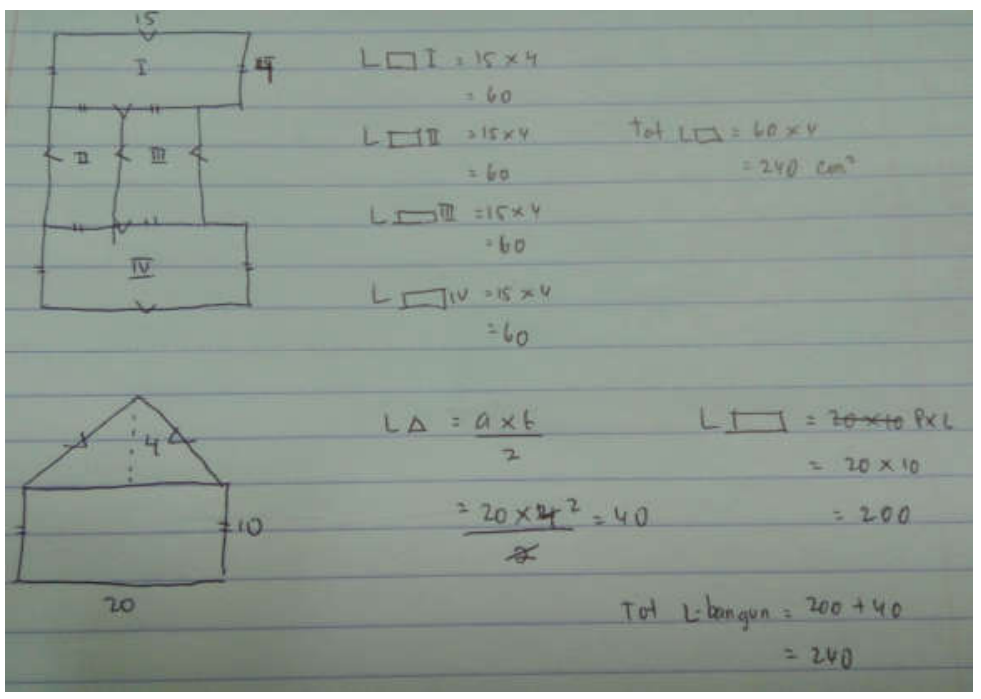

Figure 1. Sample of student work in upper category

The results of interviews with student in upper category as follow.

Question: With the available time, you made two alternative answers were correct. What did you do?

Answer : First, I made a plane figure arrangement which has the same area with the given plane figure. After I found the right answer, I checked out a minute later and then I looked for another arrangement.

Question : Did you found it difficult to determine the area of plane figure arrangement?

Answer : No, I didn't. Because I have ever did the same problem to find the area of some plane figures.

For students in middle category, they can solve the problems by producing an alternative answer. It can be seen in Figure 2.

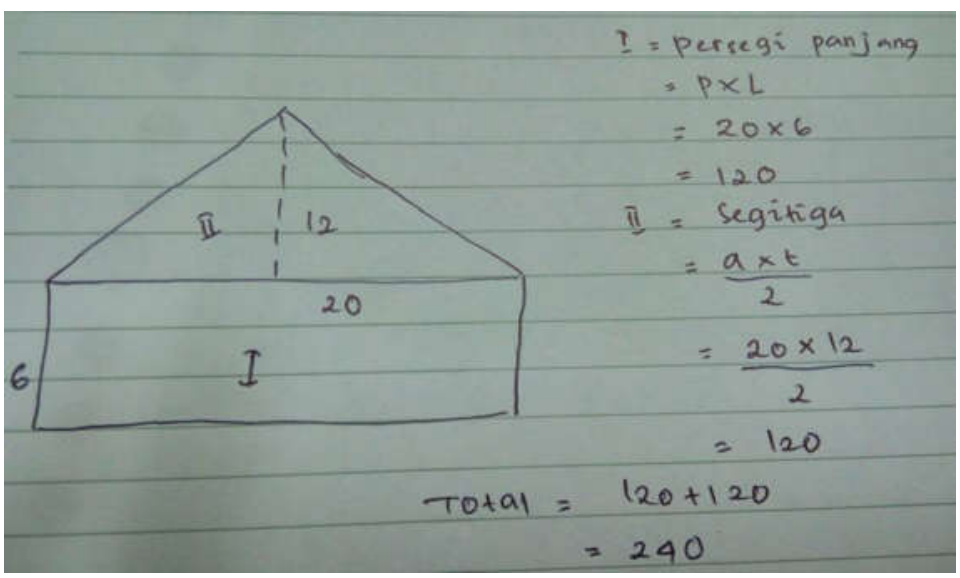

Figure 2. Sample of the Student Work in Middle Category 
The results of interviews with student in middle category as follow.

Question : With the available time, you made two alternative answers were correct. What did you do?

Answer : I lack of attention to the available time. I was busy tried to find the plane figure arrangement.

Question : Did you have time to verify your answer?

Answer : Because I was in a rush in doing, I didn't have time to check again my answer.

Finally, for students in lower category, they have difficulty to determine the plane figure arrangement. They just showed streaks calculation, but they haven't made a specific plane figure arrangement in their answer sheet. The results of interviews with student in lower category as follow.

Question : With the available time, you didn't make an alternative answers were correct. What did you do?

Answer : I feel confused. I had difficulty to find the plane figure arrangement.

Result of the student work in upper category, on the answer sheet show that they can understand the given problem well. This means that the preparation stage has been done, where they have knowledge to solve the problem. In incubation stage, they tried to think of the arrangement in a few minutes. Until the illumination stage, they immediately make some alternative arrangements, apply their idea and made a plane figure arrangements. In verification stage, they look back at their works and then after they believe that the answer is right, they make the other plane figure arrangements. This is where students do creative thinking process stages Wallas well. As stated in the interview, that they have become familiar with the problem relating to the area of plane figure. This is inline with results of previous studies that students who arrived at the expected goals namely creative thinking ability, need to be given a habituation to each stage of creative thinking process.

On the other hand, the events that occurred on the student in middle category, they did imperfection in the stages of creative thinking process based on Wallas. There is an emotional aspect that brings students to become unfocused in the creative thinking process. Students can understand the given problem in the preparation stage. But in incubation stage, students think a little longer to finally find an arrangement while they make calculation first in the other sheet. After finding the appropriate plane figure arrangement (reach the illumination stage), they make the arrangement in the answer sheet. When the answer has been completed, they didn't check the results again and continue to think the other arrangement. This was because they require a longer time to find the arrangement. They have tried to make some arrangements, but the results are not right so they try to change the arrangement to another arrangement.

The student's work in lower ability of creative thinking indicates that students have difficulty in determining the area of plane figure arrangement. Student's answer sheet only shows streak of calculation, but they haven't made a specific plane figure arrangement. This is where students really have difficulties in solving mathematic problem. With more intensive scaffolding, teacher will be able to help them.

Based on student's mathematics creative thinking ability in solving mathematics problems, students suggest that their ability are still low. Majority of students did not 
fulfill all the stages of creative thinking process well enough. This was because they experienced obstacles to go beyond each stage in creative thinking process. Students in lower category have experienced obstacles at early stage, while students in middle category have experienced obstacles in the verification stage. Only students in upper category who were able to go beyond every stage of creative thinking well.

The result of the deeper analysis of student's work and interviews show that the process of student's creative thinking in solving mathematics problem based on the model of Wallas are divided into three categories. It can be seen in Table 1 . Analysis from the interviews showed that each student of three categories have different characteristics in each stage of Wallas model. This result shows that students in upper category do not have a difficulty in every stage of creative thinking process. They can solve the problem clearly and can provide various ways to answer. Students also can explain the solution clearly and detailly. Students in middle category in illumination stage show that they always try to solve a problem in any variety of ways. But sometime they make an error when applied their idea and they change or make a new solution, when in fact they can correct the solution without looking for the new solution.

Table 1. Creative thinking process in solving mathematics problems based on wallas model

\begin{tabular}{|c|c|c|c|}
\hline $\begin{array}{l}\text { Wallas's } \\
\text { Stage }\end{array}$ & $\begin{array}{c}\text { Upper Category of } \\
\text { Creative Thinking } \\
\text { Ability }\end{array}$ & $\begin{array}{c}\text { Middle Category of } \\
\text { Creative Thinking } \\
\text { Ability }\end{array}$ & $\begin{array}{c}\text { Lower Category of } \\
\text { Creative Thinking } \\
\text { Ability }\end{array}$ \\
\hline Preparation & $\begin{array}{l}\text { Students } \\
\text { understood the } \\
\text { problems and could } \\
\text { communicate } \\
\text { information } \\
\text { obtained well and } \\
\text { use their own } \\
\text { language }\end{array}$ & $\begin{array}{l}\text { Students were able } \\
\text { to understand the } \\
\text { problems, but in } \\
\text { communicating } \\
\text { information } \\
\text { obtained students } \\
\text { still use the } \\
\text { problems language }\end{array}$ & $\begin{array}{lr}\text { Students didn't } \\
\text { understand the } \\
\text { problems and less } \\
\text { able } \\
\text { communicate any } \\
\text { information } \\
\text { obtained }\end{array}$ \\
\hline Incubation & $\begin{array}{l}\text { Students tend to } \\
\text { stop for a moment to } \\
\text { observe a given } \\
\text { problems and } \\
\text { remember the } \\
\text { material that they } \\
\text { learn previously }\end{array}$ & $\begin{array}{l}\text { Students tend to } \\
\text { stop for a moment } \\
\text { to observe the } \\
\text { given problems } \\
\text { and try to make } \\
\text { scribble on a blank } \\
\text { paper }\end{array}$ & $\begin{array}{l}\text { Students tend to } \\
\text { stop a bit longer } \\
\text { and think about } \\
\text { what to do }\end{array}$ \\
\hline Illumination & $\begin{array}{l}\text { Students applied the } \\
\text { idea to solve the } \\
\text { problem with } \\
\text { confidence and have } \\
\text { the correct solution }\end{array}$ & $\begin{array}{l}\text { Students applied } \\
\text { the idea to solve } \\
\text { the problem and } \\
\text { the solution was } \\
\text { generally true }\end{array}$ & $\begin{array}{l}\text { Students didn't } \\
\text { clear in } \\
\text { implementing the } \\
\text { idea to solve the } \\
\text { problem and the } \\
\text { solution obtained } \\
\text { was wrong }\end{array}$ \\
\hline Verification & $\begin{array}{l}\text { Students rechecked } \\
\text { the solution. When } \\
\text { finding an error they }\end{array}$ & $\begin{array}{l}\text { Students } \\
\text { rechecked } \\
\text { solution. }\end{array}$ & $\begin{array}{lr}\text { Student } & \text { didn't } \\
\text { recheck } & \text { the } \\
\text { solution } & \text { because } \\
\end{array}$ \\
\hline
\end{tabular}

IJEME, Vol. 1, No. 2, September 2017, 177-184 


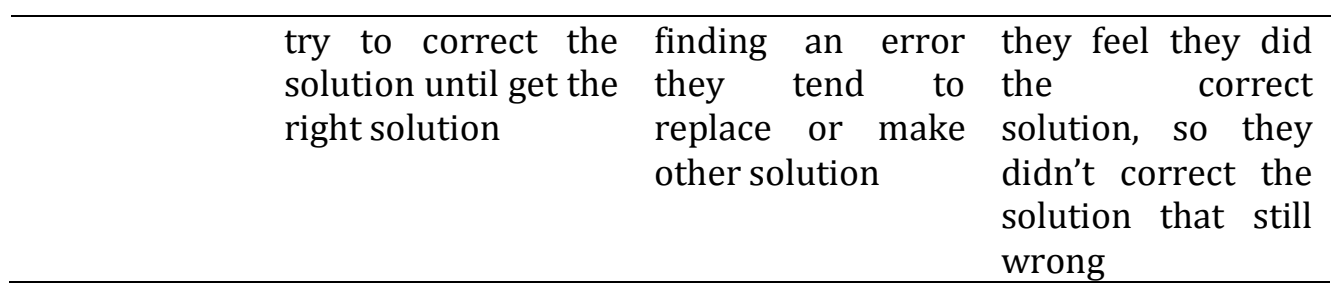

Students in lower category from the beginning in preparation stage, they already have difficulties. They do not understand with the given mathematics problems and tasks. Beside, they do not have any information or knowledge that can be used to solve the problems. Consequently, students are unclear in implementing the idea to solve the problem and the solution obtained is also wrong. This result is in accordance with Potur \& Barul (2009) that state students differ from one another in levels of motivation, backgrounds, attitudes towards teaching and learning, as well as the different responses to the classroom environment and certain instructional practices. So, students have different process in creative thinking too. In this study, students have differences in their creative thinking process.

\section{CONCLUSION}

Creative thinking ability is an ability that is important for everyone, not just when studying at school, but also when face with the world of work. In mathematics learning especially in geometry for junior high school, teachers and researchers can develop learning involves divergent thinking so as to enhance the student's creative thinking ability. Teachers can provide more opportunities for students to explore answers or solution that can lead to a creative thinking process. Based on the model of Wallas (2014), has four stages of creative thinking process that include preparation, incubation, illumination, and verification. Results of this study, students were given a mathematics problem to solve in order to measure the ability of creative thinking. The results showed 1) $23,33 \%$ of students only reached preparation stage, called the low category, 2) $60 \%$ of students reached illumination stage though to arrive at this stage students takes a long time, called middle category, and 3) $16,67 \%$ of students have completed up to verification stage, called upper category.

Students in lower category have difficulty to solve a mathematics problem. Therefore they needs more intensive guidances from teachers to assist them in performing each stage in the creative thinking process. For students in middle category teachers need to provide a little guidance and motivation to students when they did an error in solving the problem until they find the right solution. Students who have in upper category have been through the creative thinking process fluently, so teachers need to provide further enrichment materials.

\section{REFERENCES}

Aldous, C.R. (2007). Creativity, problem solving and innovative science: Insights from history, cognitive psychology and neuroscience. International Education Journal, 8(2), 176-186.

Bloom. B.S., et al. (1956). Taxonomy of Educational Goals. Canada: David McKay Company, Inc.

Bonaci, C.G., Mustata, R.V. \& Lenciu, A. (2013). Revisiting bloom's taxonomy of educational objectives. The Macrotheme Review, 2(2), 1-9. 
Huitt, W. (2011). Bloom et al.'s Taxonomy of the Cognitive Domain. Educational Psychology Interactive. Valdosta, GA: Valdosta State University.

IACBE. (2014). Bloom's Taxonomy of Educational Objectives and Writing Intended Learning Outcomes Statements. USA: The International Assembly for Collegiate Business Education.

Krathwohl, D.R. (2002). A revision of Bloom's Taxonomy: An overview. Theory Into Practice, 41(4), 212-218.

Kwon, O.N., Park, J.S., \& Park, J.H. (2006). Cultivating divergent thinking in mathematics through an open-ended approach. Asia Pacific Education Review, 7(1), 51-61.

Maharani, H.R., \& Sukestiyarno. (2015). Learning analysis based on humanism theory and mathematics creative thinking ability of students. International Journal of Education and Psychology, 1(2), 11-18.

Pehkonen, E. (1997). The state-of-art in mathematical creativity. ZDM, 29(3), 63-67.

Potur, A.A., \& Barkul, O. (2009). Gender and creative thinking in education: A theoretical and experimental overview. Journal of ITU A/ Z, 6(2), 44-57.

Runisah, Herman, T., \& Dahlan, J.A. (2017). Using the 5E learning cycle with metacognitive technique to enhance students'mathematical critical thinking skills. International Journal on Emerging Mathematics Education, 1(1), 87-98.

Sari, E.P. \& Sukestiyarno. (2014). Pemanfaatan media lingkungan dalam pembentukan karakter kemandirian siswa pada pembelajaran matematika model PBL pendekatan konstruktivisme. Proceedings of the National Conferenfe on Conservation for Better Life (NCCBL), Semarang State University, pp. 350-357.

Wallas, G. (2014). The Art of Thought. England: Solis Press.

Wessels, H. (2014). Levels of mathematical creativity in model-eliciting activities. Journal of Mathematical Modelling and Application, 1(9), 22-40.

Widiastuti, M.M.H., \& Sukestiyarno. (2014). Pemanfaatan lingkungan sekolah guna menunjang pembelajaran matematika dengan model cycle $7 \mathrm{E}$ dalam rangka membentuk karakter rasa ingin tahu siswa dan pemecahan masalah. Proceedings of the National Conferenfe on Conservation for Better Life (NCCBL), Semarang State University, pp. 331-338.

Wulandari \& Sukestiyarno. (2015). Development of ATONG based reference module for school geometry subject and analysis of mathematical creative thinking skills. Paper of the International Conference on Mathematics, Science, and Education (ICMSE), Semarang State University. 